Izvirni znanstveni članek/Original scientific article

\title{
Uporaba novih psihoaktivnih snovi med študenti zdravstvenih in pedagoških poklicev
}

\section{The use of new psychoactive drugs among students of health and teaching professions}

\author{
Eva Bučan, Branko Bregar
}

\begin{tabular}{l}
\hline \\
Ključne besede: sintetične \\
droge; odvisnost; uporaba drog, \\
medicinske sestre; učitelji; \\
mladi \\
Key words: synthetic drugs; \\
dependence; drug abuse; \\
nurses; teachers; young people \\
Eva Bučan, dipl. m. s.; Klinika \\
Golnik - Univerzitetna klinika \\
za pljučne bolezni in alergijo \\
Golnik, Golnik 36, 4204 \\
Golnik, Slovenija \\
Kontaktni e-naslov/ \\
Correspondence e-mail: \\
ewa.bucan@gmail.com \\
viš. pred. mag. Branko Bregar, \\
dipl. zn.; Univerzitetna \\
psihiatrična klinika Ljubljana, \\
Studenec 48, 1000 Ljubljana, \\
Slovenija, in Fakulteta za \\
zdravstvo Angele Boškin, \\
Spodnji Plavž 3, \\
4270 Jesenice, Slovenija
\end{tabular}

Članek je nastal na osnovi diplomskega dela Eve Bučan Uporaba novih sintetičnih drog med študenti (2016).

Prejeto/Received: 10.8 .2016

Sprejeto/Accepted: 15. 2. 2017

\section{IZVLEČEK}

Uvod: Nove psihoaktivne snovi so dokaj neraziskane in predstavljajo velik problem za našo družbo. Problem uživanja novih psihoaktivnih snovi se pojavlja v vseh starostnih skupinah, tudi med študenti. Namen raziskave je bil raziskati uporabo, odnos in poznavanje novih psihoaktivnih snovi med študenti.

Metode: Raziskava je temeljila na deskriptivni metodi kvantitativnega raziskovanja. V raziskavi je sodelovalo 311 študentov z dveh fakultet, ki izvajata študij zdravstvene nege, in fakultete s področja pedagoških poklicev. Podatki so bili obdelani s pomočjo deskriptivne, univariatne, bivariatne in multivariatne statistike.

Rezultati: Najbolj poznane nove psihoaktivne snovi so nekoliko starejše, kot so ekstazi ( $n=26,7,2 \%$ ), spid oziroma amfetamin $(n=26,7,2 \%)$ in LSD $(n=15,4,06 \%)$. Med fakultetami obstajajo razlike v poznavanju novih psihoaktivnih snovi $\left(\chi^{2}(2)=8,629, p=0,013\right)$. Odnos do drog je med anketiranci večinoma pretirano kritičen ali moralističen. Nove psihoaktivne snovi uživa več kot desetina anketirancev ( $n=42,13,5 \%)$. Anketiranci, ki uživajo drogo, večinoma prihajajo iz vaškega okolja $(n=29,69,04 \%)$, so kadilci $(n=33,78,57 \%)$ in uživajo alkoholne pijače $(n=37,95,24 \%)$.

Diskusija in zaključek: Za splošno poznavanje novih psihoaktivnih snovi so študentje premalo poučeni. Raziskava je pokazala potrebo po dodatnih izobraževanjih.

\begin{abstract}
Introduction: New psychoactive drugs are still fairly unexplored and represent a large problem for our society. The problem of the use of new psychoactive drugs occurs in all age groups, even among students. The purpose of the study was to investigate the use, attitudes and knowledge of new psychoactive drugs among students. Methods: The research was based on the descriptive method of quantitative research. Data were collected using an online questionnaire. The study involved 311 students from two health sciences faculties and the Faculty of Education. Data were processed by the descriptive, univariate, bivariate and multivariate statistics. Results: The most well-known new psychoactive drugs were slightly older like ecstasy ( $n=26,7.2 \%$ ), amphetamine or speed $(n=26,7.2 \%)$ and $\operatorname{LSD}(n=15,4.06 \%)$. There are differences between the faculties in their knowledge of new psychoactive drugs $\left(\chi^{2}(2)=8.629, p=0.013\right)$. Respondents' attitudes towards drugs are largely moralistic or overly critical. More than a tenth of respondents $(n=42,13.5 \%)$ use new psychoactive drugs. The respondents who used drugs, generally come from a rural environment $(n=29,69.04 \%)$, are smokers $(n=33,78.57 \%)$ and enjoy alcohol $(n=37,95,24 \%)$.

Discussion and conclusions: Students lack the general knowledge of new psychoactive drugs. The research has shown the need for additional education.
\end{abstract}




\section{Uvod}

Tako v svetu kot tudi v Sloveniji se srečujemo s problemom uživanja prepovedanih drog, kar za vsako državo predstavlja velik javnozdravstveni problem (Bregar, 2008). Poznamo naravne, polsintetične in sintetične droge. Uporaba sintetičnih drog je v svetu vedno bolj zaskrbljujoča. Vsako leto na nezakonit način nastajajo nove sintetične droge, ki so po strukturi in delovanju podobne že znanim in prepovedanim drogam (Paš \& Žiberna, 2014; McGill, 2015). Poleg izraza »sintetične droge « se za le-te pogosto uporabljajo tudi izrazi »dizajnerske droge«, »rekreativne droge « in v zadnjem času v slovenski strokovni javnosti »nove psihoaktivne snovi« (Janežič, 2005; Horowitz, et al., 2008; Pasternak, 2013; Paš \& Žiberna, 2014; Drev, 2015; Nacionalni inštitut za javno zdravje, 2015). Med najbolj poznanimi in uporabljanimi sintetičnimi drogami so spid (amfetamin), metamfetamin, ekstazi in dietilamid lisergične kisline (LSD). Ekstazi velja za predhodnika t. i. novih sintetičnih drog. V zadnjih letih se pojavljajo nove sintetične droge, med katerimi avtorji najpogosteje omenjajo: 3-metilmetkationon oz. 3-MMC (bolj znan pod imenom »sladoled «), serije NBOMe (»N-bomb«), mefedron, (»mef«), dezomorfin (»krokodil«), sintetične kanabinoide (»K2 spice«), 4-flouroamfetamin oz. 4-FA, metoksetamin, etilfenidat, ketamin in metilon (Coppola \& Mondola, 2012; Adamowicz, et al., 2016). Pri nas je bil 3-MMC prvič opažen v začetku leta 2012 in je zdaj že uvrščen $\mathrm{v}$ prvo skupino prepovedanih drog. $\mathrm{V}$ to skupino so uvrščeni tudi 25I-NBOMe, 25C-NBOMe iz serije NBOMe, 4-FA, metoksetamin (Uredba o razvrstitvi prepovedanih drog, 2016). Etilfenidat se je pojavil konec leta 2010, a v Sloveniji ni na listi prepovedanih drog. Čeprav nekatere nove sintetične droge še niso uvrščene na listo prepovedanih drog, to ne pomeni, da niso škodljive. Nove sintetične droge še niso dovolj raziskane, zato njihova razširjenost predstavlja velik zdravstveni in družbeni problem (Paš \& Žiberna, 2014).

Epidemiološka slika v Evropi kaže, da so med prepovedanimi sintetičnimi drogami najpogosteje uporabljeni amfetamini. Ker so te droge prepovedane, se nezakonito uporabljajo druge manj znane, vendar vedno bolj razširjene nove sintetične droge, kot so npr. sintetični katinoni (npr. mefedron, 3,4-metilendioksipirovaleron - MDPV), sintetični kanabinoidi in fenetilamini (npr. 4-FA). V zadnjih letih je bilo odkritih več kot 130 različnih sintetičnih kanabinoidov. V Evropi je amfetamine med prebivalstvom starosti 15-64 let $\mathrm{v}$ zadnjem letu uporabilo $0,5 \%$ oz. 1,6 milijona ljudi, kadar koli v življenju pa $3,5 \%$ oz. 12 milijonov ljudi. Med mladimi odraslimi (15-34 let) je amfetamine v zadnjem letu uporabilo $1 \%$ oz. 1,3 milijona ljudi. Ekstazi je med prebivalstvom starosti 15-64 let $\mathrm{v}$ zadnjem letu uporabilo $0,6 \%$ oz. 2,1 milijona ljudi, kadar koli v življenju pa 3,6 \% oz. 12,3 milijone ljudi. Med mladimi odraslimi (15-34 let) je ekstazi v zadnjem letu uporabilo 1,4 \% oz. 1,8 milijona ljudi (Evropski center za spremljanje drog in zasvojenosti z drogami, 2013). Epidemiološka slika v Sloveniji je podobna. Samo v letu 2013 se je pojavilo 12 in v letu 201438 novih sintetičnih drog (Drev, 2014). Pomemben podatek iz raziskave Nacionalnega inštituta za javno zdravje (NIJZ) je, da nove sintetične droge uživajo predvsem mladi. Povprečna starost ob prvi uporabi je bila 21 let (Drev, 2013). Po podatkih raziskave Eurobarometer 2014 je nove psihoaktivne snovi že poskusilo $8 \%$ Evropejcev starosti 15-24 let oz. v Sloveniji kar 13 $\%$ oseb te starostne skupine (Drev, 2015; Nacionalni inštitut za javno zdravje, 2015). Značilnost uživalcev drog je pogosta uporaba več kot ene droge hkrati. Mladi uživanje najrazličnejših drog, ki jim že tako ne poznamo pravega učinka, pogosto kombinirajo z alkoholom, kar poveča verjetnost intoksikacije. Posledice so lahko izredno neprijetne, od psihotičnih reaktivnih reakcij do smrtnih intoksikacij idr. (Guillot \& Berman, 2007; Šegrec \& Kastelic, 2010; Drev, et al., 2012; Paš \& Žiberna, 2014).

Ker so mladi najpogostejši uporabniki sintetičnih drog, so posledično raziskave izvedene tudi med študenti. Raziskava med ameriškimi študenti je tako pokazala, da so najbolj razširjene dizajnerske droge MDPV (3,4-metilendioksipirovaleron), mefedron (4-metilmetkatinon), in metilon (3,4-metilendioksimetkatinon) oz. t. i. kopalne soli (Miller \& Stogner, 2014), ki se pojavljajo tudi pri nas (Nacionalni inštitut za javno zdravje, 2015). Med angleškimi študenti Dargan in sodelavci (2010) ugotavljajo, da mefedron uporablja kar petina anketirancev, najpogosteje so ga zaužili $\mathrm{v}$ nočnih klubih. Približno polovica ga je kupila od uličnih preprodajalcev, dobra desetina celo na internetu, kar kaže na zaskrbljujočo dosegljivost novih sintetičnih drog. Raziskava o uporabi sintetične marihuane med študenti v Združenih državah Amerike (ZDA) je pokazala, da je o uporabi poročalo $69(8 \%)$ od $852 \mathrm{v}$ raziskavo vključenih študentov. Ugotovljeno je bilo, da je sintetične kanabinoide uporabljal skoraj vsak deseti študent, najpogosteje so to bili moški in študenti nižjih letnikov (Xingdi, et al., 2011). Iranska raziskava, izvedena med študenti medicine, je pokazala pogosto kajenje cigaret, pojavljala se je tudi manjša uporaba polsintetičnih in sintetičnih drog, in sicer heroina in LSD-ja (0,1 \%) (Sahraian, et al., 2010). Evropska raziskava, ki je zajela 340 študentov medicine, je pokazala, da jih je med njimi kar 16,8 \% že uživalo rekreativne droge (Horowitz, et al., 2008). Raziskava o uporabi sintetične marihuane pred vstopom na fakulteto in med študijem, ki je potekala leta 2015, je pokazala, da so študentje v 7,6\% sintetično marihuano poskusili že pred vstopom na fakulteto, 6,6 \% študentov pa je to sintetično drogo prvič uporabilo med študijem (Egan, et al., 2015). Od vzorca 2349 študentov je 25 $(1,07 \%)$ študentov priznalo, da so vsaj enkrat v 
življenju zaužili sintetične katinone (Stogner \& Miller, 2013). Raziskave v našem prostoru so na tem področju redkejše, vendar kažejo enako sliko ali morda celo bolj zaskrbljujočo (Rus, 2014). Med študenti zdravstvene nege je bilo izvedenih kar nekaj raziskav. Dittman s sodelavci (2015) ugotavljajo, da sta kemična uporaba in odvisnost med študenti zdravstvene nege pogosti. Številne situacije, ki povzročajo telesne in čustvene napetosti, so pogosto vzrok za uživanje alkohola in drugih psihoaktivnih snovi tudi pri študentih zdravstvene nege. To dokazuje tudi raziskava, $\mathrm{v}$ kateri je $47 \%$ študentov zdravstvene nege odgovorilo, da uživajo droge zato, da se lažje sprostijo (Abarca \& Pillon, 2008; Biraghi \& Tortorano, 2010). Baldwin in sodelavci (2009) ugotavljajo, da je med študenti zdravstvene nege $\mathrm{v}$ ZDA povprečna stopnja uporabe prepovedanih drog 8,3\%. Kamenšak (2014) je pri raziskovanju razširjenosti uporabe prepovedanih drog med študenti zdravstvene nege pri nas spraševala tudi o uporabi amfetamina in ekstazija. Amfetamine je uživalo $7(12,3 \%)$ študentov, ekstazi pa $5(8,8 \%)$ anketiranih študentov od skupaj $57 \mathrm{v}$ vzorec vključenih študentov zdravstvene nege. Uporaba sintetičnih drog je največja prav med mladimi, kar potrjujejo tudi zgoraj navedene raziskave.

\section{Namen in cilji}

Namen raziskave je bil raziskati uporabo, odnos in poznavanje novih sintetičnih drog med študenti, ki se izobražujejo za zdravstvene (študij zdravstvene nege) in pedagoške poklice. Zastavili smo si naslednja raziskovalna vprašanja:

- Kakšna je pojavnost uporabe novih sintetičnih drog med študenti?

- Kakšen odnos imajo študentje zdravstvenih in pedagoških poklicev do novih sintetičnih drog?

- Kateri učinki novih sintetičnih drog so najmanj zaželeni?

- Kakšna je povezanost nekaterih dejavnikov, kot sta kraj bivanja in življenjski slog, s pogostostjo uporabe novih sintetičnih drog?

\section{Metode}

Raziskava je temeljila na neeksperimentalni deskriptivni kvantitativni metodi raziskovanja.

\section{Opis instrumenta}

Podatke smo pridobili s pomočjo strukturiranega vprašalnika, ki smo ga oblikovali na podlagi pregleda literature (Sande, 2007; Dvoršek, 2008; Paš \& Žiberna, 2014). Sestavljen je bil iz štirih sklopov. Prvi sklop vprašalnika je zajemal demografske podatke in podatke o kraju bivanja, kajenju in uživanju alkohola. Drugi sklop je zajemal vprašanja o odnosu do sintetičnih drog in o neželenih učinkih. Za vprašanja o znanju, odnosu in prepričanjih smo uporabili tujo raziskavo, iz katere smo uporabili del vprašalnika (Bryan, et al., 2000); ta vprašalnik je bil v slovenskem prostoru uporabljen prvič. Od avtorja vprašalnika smo vnaprej pridobili tudi dovoljenje za uporabo. Tretji sklop vprašalnika je zajemal vprašanja o uporabi sintetičnih drog, četrti sklop pa je obsegal trditve o ekonomskem položaju, telesni kondiciji in subjektivnem zaznavanju zdravja anketirancev. $\mathrm{V}$ vprašalniku smo uporabili petstopenjsko ocenjevalno lestvico ( 1 - zelo slabo, 2 - slabo, 3 - srednje, 4 - dobro, 5 - zelo dobro) in petstopenjsko Likertovo lestvico (1 - sploh se ne strinjam, 2 - ne strinjam se, 3 - delno se strinjam, 4 - strinjam se, 5 - popolnoma se strinjam), s katerima smo ugotavljali stopnjo strinjanja. Uporabili smo tudi tristopenjsko lestvico ( 1 - zaželen, 2 - delno nezaželen, 3 - nezaželen) in zaprti tip vprašanj (z možnostjo enega ali več odgovorov). Zanesljivost vprašalnika smo merili po posameznih sklopih. Cronbachov koeficient alfa se je gibal med 0,655 in 0,901, razen za sklop desetih trditev, s katerimi smo merili odnos anketirancev do uporabe drog, tu zanesljivost ni bila potrjena (Cronbach $a=0,507)$. Zanesljivost vprašalnika smo povečali $\mathrm{z}$ izločitvijo dveh trditev iz tega sklopa (»Občasna raba prepovedanih drog ni nevarna« in »To, da mladi ljudje poizkusijo prepovedane droge vsaj enkrat, je normalno «), Cronbachov koeficient alfa za preostalih osem trditev je tako znašal 0,706.

\section{Opis vzorca}

Za ciljno populacijo smo izbrali redne in izredne študente dodiplomskega študija treh fakultet: fakulteto 1 , fakulteto 2 , obe izvajata študij zdravstvene nege (v nadaljevanju $\mathrm{F} 1$ in $\mathrm{F} 2$ ), ter fakulteto 3 s področja pedagoških poklicev (v nadaljevanju F3). Realizacije ne moremo opredeliti, ker smo spletno anketo širili prek znancev. V raziskavi je po tehniki priročnega vzorčenja sodelovalo 311 študentov od tega $264(84,9$ \%) žensk in $47(15,1 \%)$ moških. Največ študentov je bilo v starostni skupini od 21 do 23 let, in sicer 152 $(48,9 \%)$ študentov, od tega je bilo 240 (77,2\%) rednih in $71(22,8 \%)$ izrednih študentov. Največ anketiranih študentov $(121,38,9 \%)$ je s F1, sledi F2 s $107(34,4$ $\%)$ študenti in nato F3 s $83(26,7 \%)$ študenti. Več kot polovica anketiranih študentov $(181, \mathrm{tj} .58,2 \%)$ prihaja s podeželja, iz mesta je $130(41,8 \%)$ anketirancev.

\section{Opis poteka raziskave in obdelave podatkov}

Vprašalnik smo $s$ pomočjo spletne aplikacije 1KA preoblikovali v spletno anketo. Raziskavo smo izvedli na fakultetah, kjer se izobražujejo na področju zdravstvenih in pedagoških poklicev. Vprašalnike smo razposlali na elektronske naslove študentov, le-te smo za študente ene od fakultet (F1) pridobili od njihove fakultete, za druge pa preko študentskih skupin in predstavnikov letnikov. Ker želimo ohraniti 
anonimnost fakultet, smo jih označili z oznakami $\mathrm{F} 1, \mathrm{~F} 2$ in F3. Vsi sodelujoči so bili seznanjeni $\mathrm{z}$ vsebino in namenom raziskovanja in s tem, da je sodelovanje prostovoljno. Anketiranim študentom je bila zagotovljena anonimnost. Raziskava je potekala od začetka septembra do začetka novembra 2015. Podatke smo statistično obdelali s pomočjo programa SPSS verzija 22 (SPSS Inc., Chicago, IL, USA). Uporabili smo opisno statistiko (frekvence, strukturne deleže in povprečno vrednost), Levenov test, ANOVO, Welchov test, hi-kvadrat test in Kruskal-Wallisov test. $\mathrm{Za}$ statistično pomembne podatke smo upoštevali razlike s stopnjo statistične pomembnosti na ravni 0,05 in manj.

\section{Rezultati}

Od 311 anketiranih študentov jih sintetičnih drog ne uporablja 269 (86,5\%). Sintetične droge je že uporabilo $42(13,5 \%)$ anketiranih študentov, od tega $13(10,7 \%)$ študentov fakultete F1, $17(15,9$ \%) študentov fakultete F2 in 12 (14,5\%) študentov fakultete F3. Iz Tabele 1 lahko razberemo uporabo sintetičnih drog med študenti F1, F2 in F3, pri čemer je treba upoštevati, da so isti študenti lahko uporabljali

Tabela 1: Uporaba novih sintetičnih drog Table 1: The use of new synthetic drugs

\begin{tabular}{lllll}
\hline $\begin{array}{l}\text { Uporaba novih sintetičnih drog/ } \\
\text { The use of new synthetic drugs }\end{array}$ & & F1 & F2 & F3 \\
\hline \multirow{2}{*}{ Ekstazi (MDMA) } & $n$ & 5 & 11 & 10 \\
& $\%$ & 3,7 & 8,4 & 9,7 \\
\hline \multirow{2}{*}{ Spid (amfetamin) } & $n$ & 6 & 11 & 9 \\
\hline \multirow{2}{*}{ Sladoled (3-MMC) } & $\%$ & 4,5 & 8,4 & 8,7 \\
\hline \multirow{2}{*}{ Krokodil (dezomorfin) } & $n$ & 3 & 0 & 0 \\
& $\%$ & 2,2 & 0 & 0 \\
\hline K2 oz. spice (sintetični & $n$ & 1 & 0 & 1 \\
kanabinoidi) & $\%$ & 0,7 & 0 & 0 \\
\hline \multirow{2}{*}{ Mef (mefedron) } & $n$ & 2 & 1 & 1 \\
\hline \multirow{2}{*}{ LSD } & $\%$ & 1,5 & 0,8 & 1,0 \\
\hline \multirow{2}{*}{ Metilon } & $n$ & 1 & 1 & 1 \\
\hline \multirow{2}{*}{ 4-FA } & $\%$ & 0,7 & 0,8 & 1,0 \\
\hline \multirow{2}{*}{ Serije NBOMe } & $n$ & 5 & 6 & 4 \\
\hline \multirow{2}{*}{ Metoksetamin } & $\%$ & 3,7 & 4,6 & 3,9 \\
\hline Ne uporabljam nobene & $n$ & 0 & 3 & 2 \\
sintetične droge. & $\%$ & 0 & 2,3 & 1,9 \\
\hline \multirow{2}{*}{ Drugo } & $n$ & 0 & 0 & 1 \\
\hline Legenda/Legend: & $\%$ & 0 & 0 & 1,0 \\
\hline & $n$ & 0 & 1 & 1 \\
& $\%$ & 0 & 0,8 & 1,0 \\
\hline & $n$ & 0 & 1 & 1 \\
& $\%$ & 0,0 & 0,8 & 1,0 \\
\hline
\end{tabular}

Legenda/Legend: $n$-število/number; \% - odstotek/percentage; F1-fakulteta 1/faculty 1; F2 - fakulteta 2/faculty 2; F3 fakulteta $3 /$ faculty 3 več različnih sintetičnih drog. Tri najpogostejše uporabljene sintetične droge so bile: ekstazi (F2: $n=$ 11, 8,4 \%; F3: $n=10,9,7 \%$; F1: $n=5,3,7 \%$ ), spid oz. amfetamin (F1: $n=6,4,5 \%$; F2: $n=11,8,4 \%$; F3: $n=9,8,7 \%)$ in LSD (F2: $n=6,4,6 \%$; F $1: n=5,3,7$ \%; F3: $n=4,3,9 \%)$. V najmanjši meri so študenti F1 uporabljali dezomorfin oz. »krokodil « in mefedron $(n$ $=1,0,7 \%$ ), študenti F2 $» \mathrm{~K} 2$ spice«, mefedron, serije NBOMe in metoksetamin $(n=1,0,8 \%)$ in študenti F3 »krokodil«, »K2 spice«, mefedron, 4-FA, serije NBOMe in metoksetamin $(n=1,1,0 \%)$.

V nadaljevanju smoštudente spraševali o poznavanju definicije sintetičnih drog. Na voljo so imeli tri trditve: 1) "Sintetična droga označuje vsako snov rastlinskega, živalskega ali rudninskega izvora, ki se v naravni obliki ali skupaj $\mathrm{z}$ drugo snovjo uporablja $\mathrm{v}$ zdravilne namene; « (nepravilno), 2) »Sintetične droge so umetne kemikalije, ki imajo podobne psihoaktivne snovi kot nekatere prepovedane droge; « (pravilno) in 3) »Sintetične droge so naravne snovi, ki jih prvotno v neki obliki najdemo v naravi« (nepravilno). S prvo trditvijo se študentje vseh treh fakultet ne strinjajo. $\mathrm{V}$ največji meri se študenti vseh treh fakultet strinjajo $\mathrm{z}$ naslednjo trditvijo "Sintetične droge so umetne kemikalije, ki imajo podobne psihoaktivne snovi kot nekatere prepovedane droge «. Največja povprečna vrednost te trditve je pri F3 $(\bar{x}=4,10, s=0,82)$, najmanjša pa pri F2 $(\bar{X}=3,82, s=0,99)$. Ugotovili smo, da se statistično pomembne razlike pojavljajo pri trditvi "Sintetične droge so naravne snovi, ki jih prvotno v neki obliki najdemo v naravi « $\left(\chi^{2}(2)=8,629\right.$, $p=0,013)$. $S$ poskusom mnogoternih primerjav (posthoc test) smo ugotovili, da se pri poznavanju definicije sintetičnih drog statistično med seboj razlikujeta $\mathrm{F} 1$ in F3 $(F=4,529, p=0,003)$.

Raziskali smo odnos anketiranih študentov do novih sintetičnih drog z lestvico osmih trditev. Anketiranci se najbolj strinjajo s trditvijo $» V$ osnovni šoli je nujno potrebno izobraževanje o prepovedanih drogah $«(\bar{X}=$ $4,52, s=0,80)$, sledijo naslednje trditve »Ozaveščanja o nevarnosti uporabe prepovedanih drog je premalo" $(\bar{x}=3,89, s=1,09)$, »V bližini nekoga, ki uporablja prepovedane droge, se ne počutim dobro« $(\bar{x}=3,65$, $s=1,20)$, "Izogibam se ljudem, ki so zasvojeni $\mathrm{z}$ drogami $(\bar{x}=3,45, s=1,21)$, »Večina mladih danes poskusi ekstazi « $(\bar{X}=2,90, s=0,94)$, "Vse droge so enako škodljive zdravju « $(\bar{x}=2,79, s=1,32)$, »Ljudi, ki so zasvojeni s prepovedanimi drogami, vidim kot kriminalce in ne kot žrtve« $(\bar{x}=2,57, s=1,09)$ in »Že ob prvi uporabi droge si zasvojen« $(\bar{x}=2,19, s=$ $0,97)$.

Iz Tabele 2 je razvidno, da do statistično pomembnih razlik med fakultetami prihaja pri trditvah $»$ Vse droge so enako škodljive zdravju « $(\chi 2(2)=21,779, p<0,001)$, "Že ob prvi uporabi droge si zasvojen " $(\chi 2(2)=12,976$, $p=0,002)$, »Izogibam se ljudem, ki so zasvojeni z drogami « $(\chi 2(2)=7,597, p=0,022)$, »Večina mladih danes poskusi ekstazi« $(\chi 2(2)=11,019, p=0,004)$ 
in "Ljudi, ki so zasvojeni s prepovedanimi drogami, vidim kot kriminalce in ne kot žrtve« $(\chi 2(2)=8,771$, $p=0,012$ ).

Študente, ki so že kdaj uporabili nove psihoaktivne snovi, smo z lestvico od 1 do 3 spraševali, kateri učinek izmed novih sintetičnih drog je najmanj zaželen. $\mathrm{Na}$
F1 so študentje največkrat podali odgovor depresija $(\bar{x}=2,77, s=0,57)$, pri študentih F2 je v povprečni vrednosti na prvem mestu tesnoba $(\bar{X}=2,93, s=0,30)$, pri študentih F3 je bila najvišja povprečna vrednost pri občutku strahu in ogroženosti ter depresiji $(\bar{x}=2,99, s=$ $0,11)$. Do statistično pomembnih razlik med fakultetami

Tabela 2: Odnos anketirancev do novih sintetičnih drog

Table 2: The respondents' attitudes towards new synthetic drugs

\begin{tabular}{|c|c|c|c|c|c|c|c|c|}
\hline \multirow{2}{*}{$\begin{array}{l}\text { Trditve o odnosu do } \\
\text { sintetičnih drog/ } \\
\text { Statements about attitudes } \\
\text { towards synthetic drugs }\end{array}$} & \multicolumn{2}{|c|}{ F1 } & \multicolumn{2}{|c|}{ F2 } & \multicolumn{2}{|c|}{ F3 } & \multicolumn{2}{|c|}{$\begin{array}{c}\text { Kruskal-Wallis } \\
\text { test }\end{array}$} \\
\hline & $\bar{x}$ & $s$ & $\bar{x}$ & $s$ & $\bar{x}$ & $s$ & $x^{2(2)}$ & $p$ \\
\hline Vse droge so enako škodljive zdravju. & 3,23 & 1,34 & 2,57 & 1,31 & 2,43 & 1,14 & 21,779 & 0,001 \\
\hline Že ob prvi uporabi droge si zasvojen. & 2,44 & 1,06 & 2,13 & 0,96 & 1,92 & 0,75 & 12,976 & 0,002 \\
\hline $\begin{array}{l}\text { Izogibam se ljudem, ki so zasvojeni } \\
\text { z drogami. }\end{array}$ & 3,61 & 1,27 & 3,21 & 1,20 & 3,55 & 1,12 & 7,597 & 0,022 \\
\hline $\begin{array}{l}\text { V bližini nekoga, ki uporablja prepovedane } \\
\text { droge, se ne počutim dobro. }\end{array}$ & 3,77 & 1,26 & 3,46 & 1,22 & 3,73 & 1,17 & 5,010 & 0,082 \\
\hline $\begin{array}{l}\text { Ozaveščanja o nevarnosti uporabe } \\
\text { prepovedanih drog je premalo. }\end{array}$ & 4,05 & 1,06 & 3,81 & 1,17 & 3,78 & 1,04 & 4,387 & 0,112 \\
\hline Večina mladih danes poskusi ekstazi. & 3,07 & 0,94 & 2,93 & 0,95 & 2,61 & 0,88 & 11,019 & 0,004 \\
\hline $\begin{array}{l}\text { V osnovni šoli je nujno potrebno izobraževanje } \\
\text { o prepovedanih drogah. }\end{array}$ & 4,63 & 0,71 & 4,44 & 0,93 & 4,48 & 0,75 & 3,449 & 0,178 \\
\hline $\begin{array}{l}\text { Ljudi, ki so zasvojeni s prepovedanimi } \\
\text { drogami, vidim kot kriminalce in ne kot žrtve. }\end{array}$ & 2,71 & 1,08 & 2,35 & 2,67 & 1,01 & 0,012 & 8,771 & 0,012 \\
\hline
\end{tabular}

Tabela 3: Neželeni učinki

Table 3: Side effects

\begin{tabular}{|c|c|c|c|c|c|c|c|c|c|}
\hline \multirow{2}{*}{$\begin{array}{l}\text { Poznavanje neželenih } \\
\text { učinkov/ } \\
\text { Knowing the side } \\
\text { effects }\end{array}$} & \multicolumn{2}{|c|}{$F 1$} & \multicolumn{2}{|c|}{$F 2$} & \multicolumn{2}{|c|}{ F3 } & \multirow{2}{*}{$\begin{array}{l}\text { Statistični } \\
\text { test/ } \\
\text { Statistical } \\
\text { test }\end{array}$} & \multirow{2}{*}{$F$} & \multirow{2}{*}{$p$} \\
\hline & $\bar{x}$ & $s$ & $\bar{x}$ & $s$ & $\bar{x}$ & $s$ & & & \\
\hline Nespečnost & 2,26 & 0,77 & 2,43 & 0,75 & 2,60 & 0,60 & Welch & 6,12 & 0,003 \\
\hline Psihotične motnje & 2,63 & 0,68 & 2,84 & 0,46 & 2,94 & 0,33 & Welch & 9,472 & 0,001 \\
\hline Občutek strahu in ogroženosti & 2,66 & 0,67 & 2,89 & 0,37 & 2,99 & 0,11 & Welch & 16,658 & 0,001 \\
\hline Težave $\mathrm{z}$ govorom & 2,76 & 0,53 & 2,86 & 0,40 & 2,95 & 0,27 & Welch & 6,107 & 0,003 \\
\hline Nevarnost zasvojenosti & 2,74 & 0,61 & 2,89 & 0,42 & 2,96 & 0,24 & Welch & 6,582 & 0,002 \\
\hline Tesnoba & 2,75 & 0,61 & 2,93 & 0,30 & 2,96 & 0,24 & Welch & 5,902 & 0,003 \\
\hline Hiter pojav tolerance & 2,64 & 0,63 & 2,79 & 0,53 & 2,77 & 0,50 & Welch & 2,103 & 0,125 \\
\hline Težave s koncentracijo & 2,73 & 0,62 & 2,90 & 0,36 & 2,95 & 0,27 & Welch & 6,261 & 0,002 \\
\hline Občutek miru & 1,64 & 0,82 & 1,57 & 0,80 & 1,52 & 0,75 & ANOVA & 0,562 & 0,570 \\
\hline Vznemirjenost & 2,27 & 0,79 & 2,32 & 0,83 & 2,39 & 0,73 & ANOVA & 0,506 & 0,604 \\
\hline Slabost & 2,72 & 0,59 & 2,91 & 0,32 & 2,93 & 0,30 & Welch & 5,749 & 0,004 \\
\hline Bruhanje & 2,74 & 0,58 & 2,92 & 0,31 & 2,96 & 0,24 & Welch & 6,809 & 0,001 \\
\hline Prehitro bitje srca & 2,71 & 0,63 & 2,81 & 0,48 & 2,94 & 0,29 & Welch & 7,127 & 0,001 \\
\hline Depresija & 2,77 & 0,57 & 2,91 & 0,32 & 2,99 & 0,11 & Welch & 10,571 & 0,001 \\
\hline Dvig razpoloženja & 1,64 & 0,79 & 1,50 & 0,73 & 1,49 & 0,76 & ANOVA & 1,427 & 0,242 \\
\hline $\begin{array}{l}\text { Popolna izguba vizualnega } \\
\text { stika } \mathrm{z} \text { realnostjo }\end{array}$ & 2,45 & 0,75 & 2,38 & 0,75 & 2,43 & 0,75 & ANOVA & 0,216 & 0,806 \\
\hline
\end{tabular}

Legenda/Legend: $\bar{x}$ - povprečna vrednost/average value; $s$ - standardni odklon/standard deviation; $p$ - statistična značilnost/statistical significance; $F$ - Levenov test enakosti varianc/Levene's test of equality of variances; F1 - fakulteta 1/faculty 1; F2 - fakulteta 2/faculty 2; F3 - fakulteta 3/faculty 3 
Tabela 4: Uporabniki sintetičnih drog v povezavi s krajem bivanja in življenjskim slogom Table 4: Users of synthetic drugs in connection with the place of residence and lifestyle

\begin{tabular}{|c|c|c|c|c|}
\hline \multirow{2}{*}{$\begin{array}{l}\text { Vprašanja o kraju bivanja in izbranih } \\
\text { značilnostih življenjskega sloga/ } \\
\text { Questions about the place of residence and } \\
\text { selected lifestyle characteristics }\end{array}$} & \multicolumn{4}{|c|}{$\begin{array}{l}\text { Uporabniki novih sintetičnih drog/ } \\
\text { Users of new synthetic drugs }\end{array}$} \\
\hline & $\begin{array}{l}\text { Da/Yes } \\
n(\%)\end{array}$ & $\begin{array}{l}\mathrm{Ne} / \mathrm{No} \\
n(\%)\end{array}$ & $\begin{array}{l}\text { Skupaj/Total } \\
n(\%)\end{array}$ & $\chi^{2}(p)$ \\
\hline Kraj stalnega prebivališča & & & & $2,35(0,08)$ \\
\hline Podeželje & $29(9,3)$ & $152(48,9)$ & $181(58,2)$ & \\
\hline Mesto & $13(4,2)$ & $117(37,6)$ & $130(41,8)$ & \\
\hline Skupaj & $42(13,5)$ & $269(86,5)$ & $311(100)$ & \\
\hline Ste kadilec? & & & & $37,45(0,001)$ \\
\hline $\mathrm{Da}$ & $33(10,6)$ & $80(25,7)$ & $113(36,3)$ & \\
\hline $\mathrm{Ne}$ & $9(2,9)$ & $189(63,7)$ & $198(63,7)$ & \\
\hline Skupaj & $42(13,5)$ & $269(86,5)$ & $311(100)$ & \\
\hline Ali uživate alkoholne pijače? & & & & $3,01(0,059)$ \\
\hline $\mathrm{Da}$ & $40(12,8)$ & $230(74,0)$ & $270(86,8)$ & \\
\hline $\mathrm{Ne}$ & $2(0,6)$ & $39(12,5)$ & $41(13,2)$ & \\
\hline Skupaj & $42(13,5)$ & $269(86,5)$ & $311(100)$ & \\
\hline
\end{tabular}

prihaja pri enajstih nezaželenih učinkih sintetičnih drog (Tabela 3), ki so jih izpostavili anketiranci, ki so že kdaj uporabili nove psihoaktivne snovi.

VTabeli 4 vidimo, da anketiranci, ki uživajo sintetične droge v večini prihajajo iz vaškega okolja $(n=29,69 \%)$, samo $9(21 \%)$ od njih ni kadilcev in samo $2(4,8 \%)$ ne uživata alkoholnih pijač. Do statistično pomembnih razlik prihaja med skupinama kadilec/nekadilec in uporabnik/neuporabnik novih sintetičnih drog $\left(\chi^{2}=\right.$ $37,45, p<0,001)$, delež uporabnikov novih sintetičnih drog je večji med kadilci kot med nekadilci.

\section{Diskusija}

»Sintetične droge so nenehno razvijajoče in zadnja leta hitro spreminjajoče se kemično vesolje; prav zaradi teh novosti se danes $\mathrm{v}$ javnosti precej govori o t. i. novih sintetičnih drogah« (Paš \& Žiberna, 2014 , p. 39). V naši raziskavi, izvedeni med študenti zdravstvene nege in študenti pedagoških poklicev, je vsak osmi anketiranec že uporabil katero od sintetičnih drog. Za ti dve skupini menimo, da sta si na določen način podobni, saj gre pri obeh, kot pravi Selič (2010), za izrazit stik in delo z ljudmi.

Rezultati naše raziskave so pokazali, da so študenti vseh treh vključenih fakultet že uporabili katero od sintetičnih drog. Več kot desetina anketiranih je že uporabilo sintetično drogo, kar ugotavljajo tudi Baldwin in sodelavci (2009) in zaključujejo, da je povprečna stopnja uporabe prepovedanih drog med študenti zdravstvene nege $\mathrm{v}$ ZDA 8,3\%. Najbolj razširjeni so ekstazi in amfetamini (Kostnapfel Rihtar \& Kastelic, 2005). Tudi v naši raziskavi so bile te sintetične droge najpogosteje uporabljene. Po podatkih Rus (2014), ki je raziskovala razširjenost uporabe sintetičnih drog med študenti v Sloveniji, je bilo ugotovljeno, da je največ študentov že uporabilo ekstazi in amfetamine. Ekstazi je uporabljalo že uporabilo 77 (6,65 \%) študentov, od teh jih je 36 (46,8 \%) v času anketiranja ekstazi še vedno uporabljalo, amfetamine pa je $\mathrm{v}$ svojem življenju poskusilo 48 $(4,1 \%)$ študentov. $\mathrm{V}$ naši raziskavi je poleg zgoraj že omenjenih dveh sintetičnih drog med pogosteje uporabljenimi tudi LSD. Na uporabo LSD (4,8 \%) med študenti Univerze v Ljubljani kaže tudi Nacionalno poročilo o stanju na področju prepovedanih drog $\mathrm{v}$ Republiki Sloveniji (Drev, et al., 2009).

Amfetamini in ekstazi so od sintetičnih drog najpogosteje uporabljeni prepovedani stimulansi $\mathrm{v}$ Evropi. Ker so te droge prepovedane, se nezakonito uporabljajo druge manj znane, vendar vedno bolj razširjene nove sintetične droge npr. sintetični katinoni (npr. mefedron, MDPV), sintetični kanabinoidi in fenetilamini (npr. 4-FA). Sintetični 
katinoni se pogosto uporabljajo na enak način kot drugi stimulansi, npr. ekstazi, in jih lahko oz. jih pogosto zamenjamo. V Sloveniji so najbolj razširjeni sintetični katinoni, med njimi je najbolj priljubljen 3-MMC (Nacionalni inštitut za javno zdravje, 2015), kar potrjuje tudi spletna raziskava o novih sintetičnih drogah v starostni skupini $15-40$ let, ki je prav tako pokazala, da je največ anketiranih uporabnikov drog uporabilo 3-MMC oz. »sladoled« $(67,0 \%)$, sledijo metilon (43,0 \%), mefedron (37,3\%), serije NBOMe, 4-FA $(24,1 \%)$ in sintetični kanabinoidi (18,5\%) (Drev, 2015; Nacionalni inštitut za javno zdravje, 2015). $\mathrm{Na}$ zelo razširjeno uporabo mefedrona in metilona opozarjata tudi Miller in Stogner (2014), ki sta izvedla raziskavo med študenti v ZDA. Tudi v naši raziskavi so bile te sintetične droge, sicer $\mathrm{v}$ manjši meri, že uporabljene. Med angleškimi študenti Dargan in ostali (2010) ugotavljajo, da mefedron uporablja kar petina anketirancev, najpogosteje so ga zaužili $\mathrm{v}$ nočnih klubih. Približno polovica ga je kupila od uličnih preprodajalcev, dobra desetina pa celo na internetu, karkaže na zaskrbljujočo dosegljivost novih sintetičnih drog. Sintetična marihuana jev zadnjem času razširjena po celem svetu, razširjenost katere potrjuje raziskava, ki kaže, da je sintetične kanabinoide uporabljal skoraj eden od desetih študentov, najpogosteje moški in študenti nižjih letnikov (Xingdi, et al., 2011). Raziskava o uporabi sintetične marihuane med študenti v ZDA je pokazala, da kar $69(8 \%)$ od 852 v vzorec vključenih študentov uporablja sintetično marihuano (Miller \& Stogner, 2014). Tudi v naši raziskavi se je izkazalo, da anketiranci uporabljajo sintetično marihuano.

$\mathrm{V}$ raziskavi smo študente spraševali o uporabi sintetičnih drog $\mathrm{v}$ povezavi $\mathrm{z}$ življenjskim slogom in krajem bivanja. Zanimiv je podatek, da več študentov, ki uporabljajo sintetične droge, prihaja iz vaškega okolja, kar nas vodi do zaključka, da so posamezniki, ki prihajajo $\mathrm{v}$ mesto iz vaškega okolja bolj ogroženi $\mathrm{v}$ novem svetu, ko so brez nadzora staršev. Od tistih študentov, ki uporabljajo sintetične droge, jih kadi več kot polovica. Iz rezultatov raziskave je razvidno, da večina študentov, ki uporabljajo sintetične droge, uživa tudi alkohol, kar lahko potrdimo tudi $\mathrm{z}$ raziskavo, v kateri so ugotovili, da je 69,9 \% najstnikov, ki uživajo alkohol, uporabljalo tudi prepovedane droge (Alcoholrehab, 2008). Pri uporabnikih ekstazija ali amfetaminov je bila opažena hkratna raba alkohola. Osebe, ki pogosto uživajo alkohol, so poročale o veliko višjih ravneh uporabe amfetaminov ali ekstazija (Evropski center za spremljanje drog in zasvojenosti z drogami, 2009).

Podoba uživanja drog, kot jo po svetu predstavljajo mediji, ter negativna stališča celotne družbe veliko vplivajo tudi na razvoj študentov zdravstvene nege (Harling \& Turner, 2012). Zato smo se odločili, da $\mathrm{v}$ svoji raziskavi ugotovimo odnos anketirancev do uporabnikov drog. V raziskavi, ki so jo izvedli na Irskem leta 2000, se je s trditvijo, da se mora izobraževanje o drogah začeti že v osnovni šoli, strinjalo $94,5 \%$ anketirancev; s trditvijo, da občasna raba ekstazija ni nevarna, se ni strinjalo 81,5 \% anketirancev (Bryan, et al., 2000). V največji meri se $s$ trditvijo glede izobraževanja o prepovedanih drogah $\mathrm{v}$ osnovni šoli strinjajo tudi študenti $v$ naši raziskavi. Zanimivo je, da se v naši raziskavi študenti v večji meri strinjajo, da so uporabniki drog kriminalci in ne žrtve, kar kaže na moralističen odnos do uporabnikov drog. Bryan in sodelavci (2000) v svoji raziskavi ugotavljajo, da je na Irskem javno mnenje nekako porazdeljeno, saj 45 \% ljudi meni, da so odvisniki kriminalci, 33 \% pa jih meni, da so žrtve, kar kaže, da imajo naši anketiranci izrazito negativna prepričanja o uporabnikih prepovedanih drog. Prav tako je pomembno poudariti, da je iz nekaterih trditev, s katerimi smo merili odnos anketirancev do uporabe drog, moč zaznati, da so anketiranci z obeh zdravstvenih fakultet v povprečju bolj obsojajoči in gojijo bolj negativen odnos do uporabnikov drog kot pa anketiranci pedagoških poklicev. Podatek je zaskrbljujoč, saj bi po našem mnenju morale biti medicinske sestre nevtralne $\mathrm{v}$ odnosu do različnih skupin pacientov, saj je dokazano, da negativna prepričanja močno vplivajo na zdravstveno obravnavo (Pillon \& Laranjeira, 2005; Bregar, 2010). Nasprotno lahko omenimo raziskavo, ki jo je izvedla Sambolić (2013), ki na manjšem vzorcu zaposlenih $\mathrm{v}$ zdravstveni negi ugotavlja, da anketiranci večinoma nimajo obsojajočih prepričanj o uporabnikih prepovedanih drog, kar mogoče kaže tudi na to, da se pri zaposlenih $\mathrm{v}$ zdravstveni negi nemoralističen pogled na uživalce drog oblikuje šele po končanem študiju. Vsekakor je problem odnosa do obremenjenih skupin pacientov $\mathrm{v}$ zdravstvenih poklicih prisoten, zato ga je potrebno resno jemati (Bregar, 2010).

Obravnavana tema je občutliiva, saj prepovedne droge niso zakonite, zato obstaja možnost, da na določena vprašanja študentje niso odgovarjali verodostojno in so tako vplivali na naše rezultate. Rezultati bi bili verodostojnejši, če bi bil vzorec večji. Vzorec je bil nenaključen, zato ne moremo govoriti o posplošitvi rezultatov. Ena od omejitev je tudi, da je v naši raziskavi sodelovalo več oseb ženskega spola. Splošno znano pa je, da je med uživalci drog več oseb moškega spola (Drev, et al., 2009), kar pomeni, da vzorec ni bil uravnotežen glede na spol.

\section{Zaključek}

Splošna pojavnost novih sintetičnih drog je $\mathrm{v}$ Sloveniji v primerjavi $\mathrm{z}$ ostalimi državami Evrope v povprečju visoka. Raziskali smo njihovo uporabo in odnos do njih pri študentih zdravstvenih in pedagoških poklicev. V raziskovalnem vzorcu več kot desetina študentov uživa nove sintetične droge, kar ni malo in kaže na to, da je pojavnost uporabe novih sintetičnih drog visoka tudi med skrbstvenimi poklici. 
Podatki razkrivajo, da so droge prisotne tudi med študenti, ki se izobražujejo za skrbstvene poklice (kot sta zdravstvena nega in pedagoški poklic), to je med posamezniki, ki bodo skrbeli za najbolj občutljivo populacijo. Kljub razmeroma velikemu deležu prisotnosti novih sintetičnih drog med anketiranimi je zaskrbljujoč njihov prevladujoč moralističen odnos do uporabnikov drog, le-ta je med anketiranci bolj značilen za študente zdravstvene nege. Vsekakor gre $\mathrm{v}$ primeru naše raziskave za eno prvih in večjih raziskav, izvedenih med študenti skrbstvenih poklicev. Hkrati je tudi pomembno, da so pri delu s študenti pomembne tudi vsebine s področja odvisnosti, saj je to problem, $s$ katerim se v poklicnem in zasebnem življenju bodoči strokovnjaki lahko pogosto srečujejo.

\section{Nasprotje interesov/Conflict of interest}

Avtorja izjavljata, da ni nasprotja interesov./The authors declare that no conflicts of interest exist.

\section{Financiranje/Funding}

Raziskava ni bila finančno podprta./The study received no funding.

\section{Etika raziskovanja/Ethical approval}

Raziskava je pripravljena v skladu z načeli HelsinškoTokijske deklaracije (World Medical Association, 2013) in v skladu s Kodeksom etike v zdravstveni negi in oskrbi Slovenije (2014)./The study was conducted in accordance with the Helsinki-Tokyo Declaration (World Medical Association, 2013) and the Code of Ethics for Nurses and Nurse Assistants of Slovenia (2014).

\section{Prispevek avtorjev/Author contributions}

Prva avtorica članka je izvedla raziskavo, statistično analizo podatkov in napisala osnutek članka. Soavtor članka je prispeval pri konceptualni zasnovi in metodologiji raziskave in pripravi predstavitve rezultatov in diskusije./The first author of the article performed the research, statistical analysis of the data and wrote the draft of the article. The second author contributed to the study design and methodology as well as to drafting the results and discussion.

\section{Literatura}

Abarca, A.M. \& Pillon, S.C., 2008. Nursing students' perception regarding predicting factors of drugs use. Revista LatinoAmericana de Enfermagem, 16(Spec. no.), pp. 607-613. https://dx.doi.org/10.1590/S0104-11692008000700017 PMid:18709283
Adamowicz, P., Gieroń, J., Gil, D., Lechowicz, W., Skulska, A. \& Tokarczyk, B., 2016. The prevalence of new psychoactive substances in biological material: a three-year review of casework in Poland. Drug testing and analysis, 8(1), pp. 63-70.

https://dx.doi.org/10.1002/dta.1924

PMid:26666629

Alcoholrehab, 2008. Connection between alcohol and drugs. Available at:

http://alcoholrehab.com/drug-addiction/connection-betweenalcohol-and-drugs/ [10.9.2016].

Baldwin, J.N., Bartek, J.K., Scott, D.M., Davis-Hall, R.E. \& DeSimone, E.M., 2009. Survey of alcohol and other drug use attitudes and behaviors in nursing students. Substance Abuse, 30(3), pp. 230-238.

https://dx.doi.org/10.1080/08897070903040964

PMid:19591059

Biraghi, E. \& Tortorano, A.M., 2010. Tobacco smoking habits among nursing students and the influence of family peer smoking behaviour. Journal of Advanced Nursing, 66(1), pp. 33-39. https://dx.doi.org/10.1111/j.1365-2648.2009.05135.x PMid:19968728

Bryan, A., Moran, R., Farrell, E., \& O'Brien, M., 2000. Drugrelated knowledge, attitudes and beliefs in Ireland: report of a nation-wide survey. Dublin: The Health Research Board. Available at:

http://www.drugs.ie/resourcesfiles/research/2000/852-1614.pdf [10. 3.2015].

Bregar, B., 2008. Odvisnost od prepovedanih drog - teorija in praksa. In: B. Možgan, ed. Obravnava bolnika, odvisnega od prepovedanih drog: zbornik prispevkov, Ljubljana, 18. april 2008. Ljubljana: Zbornica zdravstvene in babiške nege, Zveza strokovnih društev medicinskih sester, babic in zdravstvenih tehnikov Slovenije, Sekcije medicinskih sester in zdravstvenih tehnikov v psihiatriji, pp. 19-35.

Bregar, B., 2010. Učinkovita zdravstvena obravnava odvisnega pacienta. In: B. Bregar \& R. Sotler, eds. Delo z odvisnimi - povezovanje primarnega s sekundarnim zdravstvenim varstvom: zbornik prispevkov $z$ recenzijo, Ljubljana, 11. junij 2010. Ljubljana: Zbornica zdravstvene in babiške nege Zveza strokovnih društev medicinskih sester, babic in zdravstvenih tehnikov Slovenije, Sekcija medicinskih sester in zdravstvenih tehnikov v psihiatriji, pp. 46-49.

Coppola, M. \& Mondola, R., 2012. Synthetic cathinones: chemistry, pharmacology and toxicology of a new class of designer drugs of abuse marketed as "bath salts" or "plant food". Toxicology Letters, 211(2), pp. 144-149. https://dx.doi.org/10.1016/j.toxlet.2012.03.009 PMid:22459606 
Dargan, P.I., Albert, S. \& Wood, D.M., 2010. Mephedrone use and associated adverse effects in school and college/university students before the UK legislation change. Monthly Journal of the Association of Physicians, 103(11), pp. 875-879.

https://dx.doi.org/10.1093/gjmed/hcq134

PMid:20675396

Dittman, P.W., 2015. Chemical dependency and nursing students: a complicated process calling for nurse educator involvement. Journal of Addictions Nursing, 26(2), pp. 58-61. http://dx.doi.org/10.1097/JAN.0000000000000072

PMid:26053077

Drev, A., Cerar, M. \& Štokelj, R., 2009. Nacionalno poročilo 2009 o stanju na področju prepovedanih drog $v$ Republiki Sloveniji: Slovenija novosti, trendi in poglobljene informacije o izbranih temah. Ljubljana: Inštitut za varovanje zdravja Republike Slovenije. Available at: http://www.nijz.si/sites/www.nijz.si/files/publikacijedatoteke/nacionalno porocilo o stanju drog 2009.pdf[3.9.2016].

Drev, A., Štokelj, R. \& Krek, M., 2012. Nacionalno poročilo 2012 o stanju na področju prepovedanih drog $v$ Republiki Sloveniji: Slovenija novosti, trendi in poglobljene informacije o izbranih temah. Ljubljana: Inštitut za varovanje zdravja Republike Slovenije. Available at: http://www.nijz.si/sites/www.nijz.si/files/publikacijedatoteke/nacionalno porocilo o stanju drog 2012.pdf [3.4.2016].

Drev, A., 2013. Nacionalno poročilo 2013 o stanju na področju prepovedanihdrogvRepublikiSloveniji:Slovenijanovostiintrendi. Ljubljana: Inštitut za varovanje zdravja Republike Slovenije. Available at: http://www.nijz.si/sites/www.nijz.si/files/publikacijedatoteke/nacionalno porocilo o stanju drog 2013.pdf [3.6.2016].

Drev, A., 2014. Nacionalno poročilo 2014 o stanju na področju prepovedanih drog $v$ Republiki Sloveniji: Slovenija novosti in trendi. Ljubljana: Nacionalni inštitut za javno zdravje.

Available at: http://www.nijz.si/sites/www.nijz.si/files/publikacijedatoteke/nacionalno porocilo o stanju drog 2014.pdf [3.6.2016].

Drev, A., 2015. Prepovedane droge: konoplja in nove psihoaktivne snovi med mladimi v Sloveniji (nelektorirana verzija). Ljubljana: Služba vlade Republike Sloveniji za razvoj in evropsko kohezijsko politiko.

Availableat:http://www.zdravjemladih.si/data-si/file/konoplja PAS.pdf [3. 4. 2015].

Dvoršek, A., 2008. Kriminalistična metodika. Ljubljana: Fakulteta za varnostne vede, pp. 395-406.

Egan, K.L., Suerken, C.K., Reboussin, B.A., Spangler, J., Wagoner, K.G., Sutfin, E.L., et al., 2015. K2 and Spice use among a cohort of college students in southeast region of the USA. The American Journal of Drug and Alcohol Abuse, 41(4), pp. 317-322. https://dx.doi.org/10.3109/00952990.2015.1043438 PMid:26030768
Evropski center za spremljanje drog in zasvojenosti $\mathrm{z}$ drogami, 2013. Poročilo o drogah v Evropi: trendi in razvoj. Luksemburg: Urad za publikacije Evropske unije. Available at: http://www.emcdda.europa.eu/attachements.cfm/att 213154 SL TDAT13001SLN1.pdf [3. 4. 2015].

Evropski center za spremljanje drog in zasvojenosti z drogami, 2009. Stanje na področju problematike droge v Evropi: letno poročilo 2009. Luxembourg: Urad za publikacije Evropske unije. Available at:

http://www.emcdda.europa.eu/system/files/publications/970/ EMCDDA AR2009 SL.pdf [3. 11. 2015].

Guillot, C.R. \& Berman, M.E., 2007. MDMA (Ecstasy) use and psychiatric problems. Psychopharmacology, 189(4), pp. 575-576. https://dx.doi.org/10.1007/s00213-006-0606-x

PMid:17061108

Harling, M.R. \& Turner, W., 2012. Student nurses' attitudes to illicit drugs: a grounded theory study. Nurse Education Today, 32(3), pp. 235-240.

https://dx.doi.org/10.1016/j.nedt.2011.05.002

PMid:21636182

Horowitz, A., Galanter, M., Dermatis, H., \& Franklin, J., 2008. Use of and attitudes toward club drugs by medical students. Journal of Addictive Diseases, 27(4), pp. 35-42.

https://dx.doi.org/10.1080/10550880802324705

PMid:19042589

Hu, X., Primack, B.A., Bamett, T.E. \& Cook, R.L., 2011. College students and use of K2: an emerging drug of abuse in young persons. Substance Abuse Treatment Prevention and Policy, 6, p. 16. https://dx.doi.org/10.1186/1747-597X-6-16

PMid:21745369; PMCid:PMC3142218

Janežič, M., 2005. Pojav in preiskave manj pogostih oblik prepovedanih drog, ki so se pojavile v Sloveniji. Varstvoslovje, 7(4), pp. 388-398.

Kamenšak, T., 2014. Razširjenost uporabe psihoaktivnih substanc pri študentih zdravstvene nege Visoke šole za zdravstveno nego Jesenice: diplomsko delo visokošolskega strokovnega študijskega programa prve stopnje "zdravstvena nega". Jesenice: Visoka šola za zdravstveno nego Jesenice, p. 28.

Kodeks etike $v$ zdravstveni negi in oskrbi Slovenije in Kodeks etike za babice Slovenije, 2014. Ljubljana: Zbornica zdravstvene in babiške nege Slovenije - Zveza strokovnih društev medicinskih sester, babic in zdravstvenih tehnikov Slovenije.

Kostnapfel Rihtar, T. \& Kastelic, A., 2005. Klubske droge. Ljubljana: Ustanova Odsev se sliši.

Available at: http://www.ustanova-odsevseslisi.si/ustanova/oodvisn-klubske-d.htm [10. 1. 2016]. 
McGill, N., 2015. Synthetic drugs: 'for sale' doesn't always mean it's safe. The Nation's Health, 45(1), p. 28.

Available at: http://thenationshealth.aphapublications.org/ content/45/1/28.full [29. 11. 2016].

Miller, B.L. \& Stogner, J.M., 2014. Not-so-clean fun: a profile of bath salt users among a college sample in the United States. Journal of Psychoactive Drugs, 46(2), pp. 147-153.

https://dx.doi.org/10.1080/02791072.2013.876520

PMid:25052791

Nacionalni inštitut za javno zdravje, 2015. Tudi v Sloveniji se povečuje uporaba novih psihoaktivnih snovi

Available at: http://www.nijz.si/sl/tudi-v-sloveniji-se-povecujeuporaba-novih-psihoaktivnih-snovi [3.4.2015].

Pasternak, J., 2013. Desinger drugs: who knew? Alaska Nurse, 63(5), p. 6.

Available at: http://www.aknurse.org/layouts/aknurse/files/ documents/AKNURSE/The\%20Alaska\%20Nurse\%20Dec13\%20Jan-14.pdf [29. 11. 2016].

Paš, M. \& Žiberna, M., 2014. Nove sintetične droge. Gea, 24, pp. $38-50$.

Pillon, S.C. \& Laranjeira, R.R., 2005. Formal education and nurses' attitudes towards alcohol and alcoholism in a Brazilian sample. São Paulo Medical Journal, 123(4), pp. 175-180. https://dx.doi.org/10.1590/S1516-31802005000400004 PMid:16389415

Rus, T., 2014. Proučevanje zlorabe prepovedanih drog med študenti univerze $v$ Ljubljani: magistrsko delo. Ljubljana: Univerza v Ljubljani, Fakulteta za farmacijo.

Available at: http://www.ffa.uni-lj.si/fileadmin/datoteke/Knjiznica/ magistrske/2014/Rus Tjasa mag nal 2014.pdf [29. 11. 2016].

Sahraian, A., Sharifian, M., Omidvar, B. \& Javadpour, A., 2010. Prevalence of Substance Abuse Among the Medical Students in Southern Iran. Shiraz E-Medical Journal, 11(4), pp. 198-202.

Available at: http://semj.sums.ac.ir/vol11/oct2010/89005.htm [29. 11. 2016].
Sambolić., D., 2013. Odnos zaposlenih v zdravstveni negi do uporabnikov prepovedanih drog: diplomsko delo visokošolskega strokovnega študijskega programa prve stopnje "zdravstvena nega". Jesenice: Visoka šola za zdravstveno nego Jesenice, p. 29.

Sande, M., 2007. Na spidu 2: stanje na področju sintetičnih drog in kokaina v Sloveniji. Ljubljana: Združenje DrogArt, p. 238.

Selič, P., 2010. Stres in izgorelost: kako je mogoče razumeti in uporabiti podatke o izgorelosti na primarni ravni zdravstvenega varstva. In: B. Bregar \& J. Peterka Novak., eds. Kako zmanjšati stres in izgorevanje na delovnem mestu: zbornik prispevkov $z$ recenzijo, Ljubljana, 12. november 2010. Ljubljana: Zbornica zdravstvene in babiške nege, Zveza strokovnih društev medicinskih sester, babic in zdravstvenih tehnikov Slovenije, Sekcije medicinskih sester in zdravstvenih tehnikov v psihiatriji, p. 7-18.

Stogner, J.M. \& Miller, B.L., 2013. Investigating the 'bath salts' panic: the rarity of synthetic cathinone use among students in the United States. Drug Alcohol Review, 32(5), pp. 545-549.

https://dx.doi.org/10.1111/dar.12055

PMid:23718639

Šegrec, N. \& Kastelic, A., 2010. Obravnava bolnika z motnjo, vezano na uživanje psihoaktivnih snovi in komorbidno psihotično motnjo. Zdravniški vestnik, 79(7/8), pp. 566-574.

Avialable at: http://www.dlib.si/?URN=URN:NBN:SI:docYGGM1WDW [29. 11.2016].

Uredba o razvrstitvi prepovedanih drog, 2016. Uradni list Republike Slovenije št. 22/16.

World Medical Association, 2013. World Medical Association Declaration of Helsinki: ethical principles for medical research involving human subjects. Journal of the American Medical Association, 310(20), pp. 2191-2194.

Avaliable at: http://www.wma.net/en/20activities/10ethics/10h elsinki/DoH-Oct2013-JAMA.pdf [1.9.2016].

Citirajte kot/Cite as:

Bučan, E. \& Bregar, B., 2017. Uporaba novih psihoaktivnih snovi med študenti zdravstvenih in pedagoških poklicev. Obzornik zdravstvene nege, 51(1), pp. 42-51. https://dx.doi.org/10.14528/snr.2017.51.1.109 